DOI https://doi.org/10.30525/978-9934-588-81-5-2.35

\title{
ПОЛІМОРФІЗМ РУUII ГЕНА РЕЦЕПТОРА ЕСТРАДІОЛУ АЛЬФА ЯК ПОКАЗНИК ДО ХІРУРГІЧНОГО ЛІКУВАННЯ ХВОРИХ НА ДОБРОЯКІСНУ ДИСПЛАЗІЮ МОЛОЧНИХ ЗАЛОЗ
}

\author{
Лукавенко I. М. \\ кандидат медичних наук, \\ асистент кафедри хірургії, ортопедії та травматологї, фтизіатрії \\ Сумський державний університет \\ м. Суми, Украӥна
}

Передпухлинні хвороби молочної залози останнім часом набули значного поширення як в Україні, так і в усьому світі. Частота доброякісної дисплазії молочної залози (ДДМЗ), профілативні форми якої є фоном для розвитку раку молочної залози (РМЗ), серед жінок репродуктивного віку становить 70-95 \%. Основним етіологічним фактором, що провокує зміни у молочній залозі, вважають порушення балансу естрогенів. Так, під впливом стероїдних гормонів проявляється проліферативна активність епітеліоцитів залози. Суттєву роль в розвитку мастопатії та РМЗ відівіграє гіперестрогенія [1,2].

3 огляду на зростання останніми десятиліттями захворюваності на проліферативні форми мастопатії та молодий вік осіб, які страждають на ці процеси, важливим залишається пошук механізмів ранньої діагностики та новітніх критеріїв оцінювання передпухлинних хвороб $[3,4]$. Однак традиційні інвазивні методики оцінювання клінічних та інструментальних показників і морфологічних змін недостатньо інформативні, а їх використання під час вагітності та лактації обмежене. У зв'язку з цим пошук молекулярно-генетичних предикторів передпухлинних захворювань має все більше значення, що й визначає актуальність даної проблеми.

Мета роботи полягала в розробці критерієв діагностики проліферативної доброякісної дисплазії молочної залози на основі імуногістохімічних та молекулярно-генетичних досліджень із метою обгрунтування показань до хірургічного лікування.

Установлення діагнозу та обстеження пацієнтів проводили із дотриманням основних положень Конвенції Ради Свропи про права людини та біомедицину, Гельсінської декларації Всесвітньої медичної 
асоціації про етичні принципи виконання наукових медичних досліджень за участі людини і Наказу МОЗ України № 616 від 03.08.2012 p.

Усі хворі проліковані хірургічно. Критеріями відбору пацієнтів у дослідження були такі ознаки: множинні первинні пухлини в одному органі; множинні первинні пухлини у різних органах; білатеральні первинні пухлини у парних органах; мультифокальність усередині одного органа; поява пухлини у ранньому віці (до 21 року); один i більше близьких родичів із тим самим типом пухлин; два родичі й більше з тим самим типом пухлини; два родичі або більше з пухлинами однієї локалізації; два родичі або більше з пухлинами, що належать до сімейного раку; два родичі і більше з рідкісною формою раку; три родичі і більше у двох поколіннях із пухлинами однієї локалізації. Критеріями винятку були: непроліферативні зміни в молочній залозі; відсутність ознак генетичної схильності до хвороб молочної залози; відмова пацієнта брати участь у дослідженні.

Наявність естрадіолу була вивчена шляхом аналізу комбінації конкурентної імуноферментної реакції і флуорисцентного визначення продуктів реакції, проведено аналіз плазми крові.

Ультразвукове дослідження проводили за допомогою ультразвукової діагностичної системи «Toshiba» Nemio XG SSA-580A (Японія). Мамографію виконували апаратом Hologic Lorad M-IV з дигітайзером Kodak Direct View Classic CR (CШA).

Вивчено 134 новоутворення молочної залози, одержаних від 84 оперованих пацієнтів. У $72(53,7 \%)$ випадках морфологічного дослідження підлягали зразки з одного органа, а у 62 (46,3 \%), видалені за двобічного ураження грудей. Середній розмір патологічного новоутворення дорівнював $(22,29 \pm 1,02)$ мм.

PvuII (міжнародна назва rs2234693) - поліморфізм 1-го інтрона, позиція на хромосомі 152.163.335, нуклеотидна заміна в положенні 1943 Т > С, визначали методом полімеразної ланцюгової реакції (PCR) 3 подальшим аналізом довжини рестрикційних фрагментів (PCR-RFLP). Була проведена ампліфікація ділянки гена за допомогою пари специфічних праймерів, синтезованих фірмою «Metabion» (Німеччина): прямого (sence) -5' CACACATCACCATTCTCAGC 3' i зворотного (antisense) - 5' TCTAGACCACACTCAGGGTCTC 3'. Проведений аналіз розподілу алелів та генотипу поліморфізму PvuII гена $\mathrm{EsR} \alpha$, розміщеного в 6-й хромосомі (6q25.1). Усі вивчені генотипи підпорядковувалися відношенню Харді - Вайнберга. 
При аналізі розподілу варіантів генотипів за поліморфізмом PvuII гена EsR $\alpha$ видалених новоутворень одержані такі результати: генотип $\mathrm{T} / \mathrm{T}-36$ (26,9\%), генотип Т/C - 71 (53,0 \%), генотип C/C - 27 (20,1 \%).

Усі пацієнтки були розподілені на три вікові групи. До першої групи (до 21 року) ввійшло 15 (17,8 \%) пацієнтів, до другої групи (22-39 років) - 43 (51,2 \%), до третьої (старше 40 років) - $26(31,0 \%)$ відповідно. Статистичний аналіз та порівняння у кожній групі рецепторного статусу за експресією EsR $\alpha$ у новоутвореннях ДДМЗ залежно від віку пацієнток показав, що EsR $\alpha$-негативні трапляються у 43,5 \% першої групи (до 21 року), у той час як EsR $\alpha$-рецепторпозитивні - y $56,5 \%$. У другій групі рецепторнегативні зразки за експресією $\operatorname{EsR} \alpha$ спостерігались у $39,4 \%$, а рецепторпозитивні - у 60,6 \%. У третій групі (старше 40 років) рецепторнегативні зразки за EsR $\alpha$ траплялись у $55,0 \%$, а рецептор позитивні - у $45,0 \%$.

Варіант зигот C/C був частішим, ніж варіант T/T у 2,3 раза і варіант $\mathrm{C} / \mathrm{C}$ - 3 такою самою частотою. У третій групі варіант гетерозигот $\mathrm{T} / \mathrm{C}$ спостерігався в 46,2 \%, що було частіше, ніж варіант гомозигот Т/T $(38,5 \%)$, у 1,2 раза та частіше, ніж варіант гомозигот $\mathrm{C} / \mathrm{C},-\mathrm{y} 3,0$ раза.

Аналіз результатів доводить, що рецепторний статус новоутворень при ДДМЗ не залежав від віку пацієнтів $\left(\chi^{2}=2,525 ; \mathrm{P}=0,283\right)$. Крім того, розподіл алельних варіантів гена EsR $\alpha$ за поліморфізмом PvuII статистично не відрізнявся в усіх вікових групах $\left(\chi^{2}=2,620\right.$; $\mathrm{P}=0,623)$. Можна стверджувати, що серед обстежених пацієнтів статистичного зв'язку між особливостями рецепторного статусу новоутворень та поліморфізмом PvuII залежно від віку не виявлено.

Залежно від локалізації новоутворень ДДМЗ пацієнти розділися на дві групи: оперовані особи з однобічним ураженням молочних залоз $54(64,29 \%)$ та оперовані особи $з$ двобічним ураженням - 30 (35,71 \%) відповідно. Установлено, що у гомозигот С/С наявність вивченого поліморфізму РvuII статистично не відрізняється від розподілу серед пацієнтів - гомозигот за основним алелем (T/T) і не призводить до особливої локалізації вогнищ ДДМЗ. У вивченій групі пацієнтів статистичного зв'язку між хворими $з$ однобічним або двобічним ураженням грудей та вивченим поліморфізмом не існує $\left(\chi^{2}=1,281 ; \mathrm{P}=0,527\right)$.

Показано, що генотип Т/Т встановлено у жінок, у яких не буває болю та набряку молочної залози, а генотип $\mathrm{C} / \mathrm{C}$ пов'язаний з розвитком мастодинії. Серед обстежених пацієнток зі скаргами на мастодинію співвідношення гомозигот за основним алелем (T/T), гетерозигот (T/C) і гомозигот за мінорним алелем (C/C) становило 20,7, 48,3 і 31,0 \% відповідно. У пацієнток, які не відмічали мастодинії, розподіл 
був іншим: T/T $-42,3 \%$, T/C $-57,7 \%, \mathrm{C} / \mathrm{C}-0 \%$. Показник Р, визначений за $\chi^{2}$-критерієм Пірсона, дорівнював 0,003 , що свідчить про достовірну різницю у розподілі алельних варіантів гена $\operatorname{EsR} \alpha$ за поліморфізмом PvuII у пацієнток залежно від наявності мастодинії.

3 огляду на вплив генетичних особливостей індивідуума на розвиток різних захворювань важливим було вивчення сімейного анамнезу. Обстежені пацієнтки розділені на дві групи відповідно до наявності PМЗ у близьких родичів. Так, до першої групи (не обтяжений сімейний анамнез) увійшла 51 (60,7 \%) хвора. До другої групи (обтяжений сімейний анамнез) увійшли 33 (39,3\%) пацієнтки. Показано, що наявність патологічного алеля (C/C) поліморфізму PvuII гена EsR $\alpha$ у досліджуваних пацієнтів не асоційована з обтяженим сімейним анамнезом на РМЗ.

Таким чином, установлено, що додаткові дослідження експресії EsR $\alpha$ та наявності патологічного C-алеля за поліморфізмом PvuII гена $E s R \alpha$ відіграють важливу роль як критерії діагностики проліферативної доброякісної дисплазії молочної залози для обгрунтування показань до хірургічного лікування. Показано, що специфіка гістологічної будови тканини, особливостей рецепторного апарату клітини та генетичних предикторів виступає важливим показником у розумінні причин та механізмів проліферації при ДДМЗ. Результати роботи будуть покладені в основу виявлення пацієнток, схильних до розвитку проліферативних форм ДДМЗ та їх своєчасного хірургічного лікування для запобігання розвитку малігнізації.

\section{Література:}

1. Onuigbo W.I. The possible relationship between mammary dysplasia and breast cancer. International Journal of Medicine and Health Development. 2007. 12(2). P. 49-50.

2. Junji Itou, Rei Takahashi, Hiroyuki Sasanuma, Masataka Tsuda, Suguru Morimoto, Yoshiaki Matsumoto, Tomoko Ishii, Fumiaki Sato, Shunichi Takeda, MasakazuToi. Estrogen induces mammary ductal dysplasia via the upregulation of myc expression in a DNA-repair-deficient condition. iScience. 2020. 23(2). P.100821.

3. Moinfar F. Essentials of diagnostic breast pathology. Springer Book. 2007. 298 (15). P. 496.

4. Lukavenko I.M., Andryushchenko V.V., Garbuzova V.Iu., Yazykov A.V. The clinical significance of pvuii polymorphism estradiol receptor alpha gene to improve diagnosis of proliferative forms of benign breast dysplasia. Georgian medical news. 2015. 238 (1). P. 12-17. 